\title{
Comparative evaluation of Doolittle, Cupkit and Karl Jenter techniques for rearing Apis mellifera Linnaeus queen bees during breeding season
}

\author{
Navneet Kaur Dhaliwal, Jaspal Singh* and Pardeep K. Chhuneja \\ Department of Entomology, Punjab Agricultural University, Ludhiana - 141004 (Punjab), INDIA \\ *Corresponding author. E-mail: jaspal_bee@pau.edu
}

Received: March 13, 2016; Revised received: April 13, 2017; Accepted: August 5, 2017

\begin{abstract}
Comparative evaluation of Doolittle, Karl Jenter and Cupkit techniques of Apis mellifera Linnaeus queen bee rearing was done during spring (mid February- mid April 2013) breeding season. The highest acceptance of cell cups $(66.00 \%)$, queen cells raising $(64.00 \%)$, their sealing $(60.67 \%)$ and emergence of gynes $(54.67 \%)$ was recorded in Cupkit apparatus. Maximum weight of newly emerged gyne was recorded in Doolittle method in plastic cell cups $(212.36 \mathrm{mg})$, while the mean weight was $184.96 \mathrm{mg}$ in case of Cupkit apparatus. Overall, Cupkit proved to be the best option for queen bee rearing because of its better performance in terms of acceptance of larvae $(66.00$ $\%)$ and the number of successfully produced gynes i.e. 16 queens/colony/cycle of 12 days.
\end{abstract}

Keywords: Apis mellifera, Cupkit, Doolittle grafting method, Karl Jenter, Queen cell cups

\section{INTRODUCTION}

Queen bees play very important role in productivity of honey bee colonies. Apart from maintaining cohesion in a colony, queen bee transfers its traits to her progeny. For higher growth and productivity of a colony, high quality young queen is highly desirable (Ruttner, 1988). In case of accidental loss of queen, a colony can produce a new queen bee from a very young larva. But if a colony is unable to do so, its survival will be at stake. In commercial apiaries, replacement of old queen bees also becomes a necessity as with age the number of eggs laid by queen declines. A queen can lay 50,30 and $10 \%$ of her eggs during first, second and third year of her life and $10 \%$ of eggs are laid in next two years (Goodman, 2008). With age, queen starts laying more number of unfertilized eggs as the number of sperms in spermatheca starts depleting. This leads to increased population of drones in a colony and reduction in population of worker bees thereby affecting productivity of the colony. As there is a need for large number of young, quality queen bees every year to maintain productivity of an apiary, queen bee rearing has become an indispensable technique for the apiaries. For improvement of the economic, behavioural and adaptive traits of honey bees modern techniques of queen rearing, selection and mating control serve as very powerful tools. Quality standards are needed for queen rearing, mating and testing with the aim of the improvement, comparison and exchange of breeding stock (Büchler et al., 2013). The development of modern queen rearing techniques started in the 19th century when Gilbert Doolittle developed a comprehensive system during 1889 for rearing queen bees which is still used widely along with some modifications. Doolittle grafting method is most widely used method for queen bee rearing where young age larva is grafted into the queen cell cups. Taking a young (12-24 hours old) larva from a worker cell and placing it into a queen cell cup is the key step in queen rearing. The larva fed on a royal jelly diet by the nurse bees transforms into the queen which is ready to emerge after 10-11 days (Woodward, 2007). Any kind of mishandling or injury to the delicate larva while transfer results in rejection of the graft. So, the process of grafting requires skill to identify the tiny (less than $24 \mathrm{~h}$ old) larva and to transfer it safely to the queen cell cup. Use of Karl Jenter and Cupkit apparatus ensures transfer of larva without any displacement and injury to the larva, alongwith the plastic queen cell cup in which it hatches, thereby making the whole process much easier, quicker and simpler while avoiding any injury to the young larvae (Gatoria et al. 2004). So, the present study was conducted to evaluate the comparative efficiency of various available Apis mellifera queen rearing techniques, viz. Doolittle grafting method, Karl Jenter apparatus and Cupkit apparatus.

\section{MATERIALS AND METHODS}

Techniques for mass rearing of $A$. mellifera queen bees i.e., Doolittle grafting method with bee wax and plastic cell cups, Cupkit apparatus and Karl Jenter apparatus were evaluated in queenless cell builder colonies during spring breeding season (mid February- mid April 2013) at the A. mellifera Campus Apiary of 
Punjab Agricultural University, Ludhiana (India). Cupkit and Karl Jenter apparatus were fitted into fully raised combs cut according to the shape and size of the apparatus. The queen bee of the selected breeder colony was confined inside the apparatus and the comb containing the apparatus was placed in the center of the brood chamber of the breeder colony. The eggs laid by the queen bee in the apparatus were received in the cell cups and cell bases of Cupkit and Karl Jenter apparatus, respectively. After completion of egg laying, queen bee was released from the apparatus and apparatus returned to the breeder colony till hatching of larvae.

After 3 days of egg laying, cell cups (in case of Cupkit apparatus) and cell bases (in case of Karl Jenter apparatus) containing less than $24 \mathrm{~h}$ old larvae were collected. Cell bases of Karl Jenter apparatus were fitted as bottom in cell wall structures to form complete cell cups. Such cell cups, were then fitted into the cell cup blocks fixed on the three bars of queen rearing frame @ 10 cell cups per bar and were given to the cell builder colony. To prepare queenless cell builder colony, queen bee from 15 bee-frame strength $A$. mellifera colonies were removed $24 \mathrm{~h}$ prior to start of the experiment. Combs inside the brood chamber of the cell builder colonies were arranged as per McKinley (1963), i.e. H S S E Y C P E S H; where H: Honey comb,

S: Sealed brood comb,

E: Comb with sealed brood near adult emergence,

Y: Brood comb with $>3$ day old larvae,

P: Pollen comb, and

$\mathrm{C}$ : Comb fitted with queen rearing frames

For Doolittle grafting method, bees wax as well as plastic cell cups were primed with diluted fresh royal jelly (Royal jelly: sterilized water- 1:1). Thereafter, larvae of less than $24 \mathrm{~h}$ age were grafted into these cell cups and were fixed on the 3 bars of queen rearing frame@10 cell cups per bar and were given to the cell builder colonies.

Extension of queen cell cup walls and nursing of the larvae given in these cell cups were taken as criteria for recording the acceptance of the cell cups. The acceptance was recorded $24 \mathrm{~h}$ after transfer of larvae, whereas raising of cell cups was recorded $72 \mathrm{~h}$ after transfer of larvae. Subsequent observations on sealing of queen cell cups, emergence of gynes and weight of freshly emerged gynes were also recorded. After necessary transformations, statistical analysis was done using Analysis of Variance (ANOVA) for Completely Randomized Design (CRD). Least significant difference (L.S.D.) values were worked out to determine the significance of differences among the mean values at $5 \%$ level of significance.

\section{RESULTS AND DISCUSSION}

The mean acceptance of queen cell cups in different queen rearing techniques ranged from 50.00 to 66.00 $\%$ (Table 1). The acceptance in Cupkit apparatus, Karl Jenter apparatus, plastic cell cups and wax cell cups were at par with respective values of $66.00,50.00$, 58.66 and $56.00 \%$. Difference in acceptance rates of Cupkit cell cups and Doolittle grafting method in plastic cell cups indicated that the graftless method has better acceptance as it avoids any injury to larva and larva is fed royal jelly from first day onwards. Raising of cell cups in Cupkit queen rearing apparatus was significantly higher $(64.00 \%)$ than in Karl Jenter apparatus (45.33 $\%)$ but was at par with cell raising in plastic and beeswax cell cups at $5 \%$ level of significance. Raising of cell cups was the minimum (45.33 \%) in Karl Jenter apparatus but it was at par with cell raising in plastic $(56.67 \%)$ and wax cell cups $(52.67 \%)$. The present results of acceptance of plastic and beeswax cell cups being at par were in conformity with results obtained by Chang (1977) who reported non-significant difference between acceptance of plastic and wax cell cups. However, many workers (El-Din and Samni, 1990; Wilde et al., 2002) have reported higher acceptance in plastic cell cups than in wax cell cups. Results of the study reported better acceptance in beeswax cell cups than reported by Nageh et al. (2010) which was $43.77 \%$ during spring season.

Sealing of cell cups (on the basis of total cell cups given) from Cupkit apparatus $(60.67 \%)$ and plastic cell cups $(55.33 \%)$ were at par with each other, and both of these were significantly better than Karl Jenter apparatus $(40.00 \%)$ at $5 \%$ level of significance (Table 1). Wax cell cups with $50.67 \%$ raising were statistically at par with Cupkit apparatus, Karl Jenter apparatus and plastic cell cups. Sealing of the queen cells (on the basis of cell cups accepted) ranged from 88.57 to 97.50 $\%$ with non-significant differences among the various queen rearing techniques. Emergence of queen bees (on the basis of cell cups given) ranged from 26.00 to $54.67 \%$ among different queen rearing techniques (Table 1). Cupkit apparatus and plastic cell cups were at par with 54.67 and $48.67 \%$ emergence of queen bees, respectively, and both were significantly better than Karl Jenter apparatus $(26.00 \%)$ and wax cell cups $(30.67 \%)$ in this respect, and the latter two were at par with each other at $5 \%$ level of significance. Similar results were obtained in case of emergence of queen bees on the basis of cell cups accepted, where Cupkit apparatus and plastic cell cups were at par with 83.28 and $83.34 \%$ emergence, respectively, and were significantly better than Karl Jenter apparatus (52.20 $\%)$ and wax cell cups $(54.73 \%)$, and the latter two were at par with each other.

Sealing of queen cells and emergence rate of queen bees on the basis of accepted cell cups were 88.57 to $97.50 \%$ and 52.20 to $83.34 \%$, respectively, which indicate that accepted cell cups are successfully sealed with higher emergence rate. If the acceptance rate of 
Navneet Kaur Dhaliwal et al. / J. Appl. \& Nat. Sci. 9 (3): 1658 -1661 (2017)

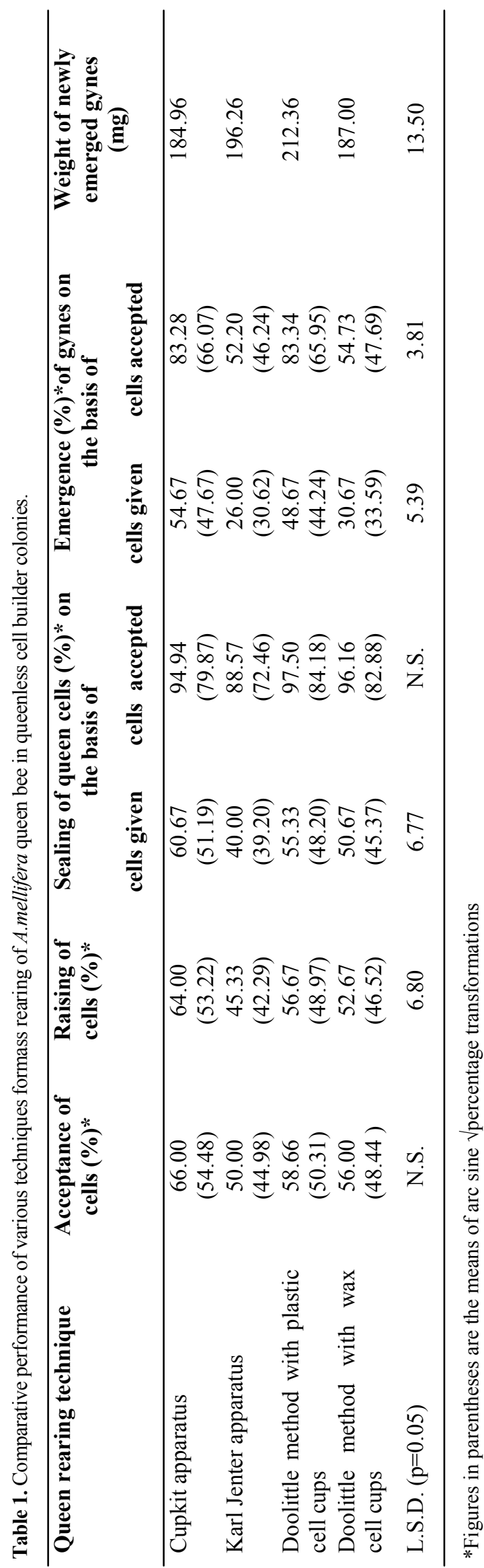

cell cups can be improved then higher success rate for mass queen bee rearing can be achieved.

The mean weight of the gynes differed significantly among the queen rearing techniques (Table 1) with the ones from plastic cell cups were significantly heavier (212.36 $\mathrm{mg}$ ) than the gynes obtained from Cupkit apparatus, Karl Jenter apparatus and wax cell cups at 5 $\%$ level of significance. The mean weight of the gynes obtained from Karl Jenter apparatus (196.26 mg) was at par with those obtained from the Cupkit apparatus $(184.96 \mathrm{mg})$, and the gynes obtained from the wax cell cups $(187.00 \mathrm{mg})$. These findings were higher than $178.47 \pm 2.05 \mathrm{mg}$ for grafting in queenless colonies reported by Dodologlu et al. (2004). Skowronek et al. (2004) also reported the average body weight of queens reared by grafting method to be in excess of $220 \mathrm{mg}$. Several workers reported emergence weight of queen bee to be more than $200 \mathrm{mg}$ (Emsen, 2003; Genc et al., 2005; Ahmad and Dar, 2013).

The study indicated that grafting in plastic cell cups can also be practiced for rearing good quality queen bees as the heaviest queen bees are obtained by this method. The per cent cell cup sealing and emergence of queen bees from grafted plastic cell cups and Cupkit apparatus cells was at par, so it is evident that if acceptance rates of plastic cell cups could somehow be improved, this method can yield higher number of good quality queens. So, those who have a skilled hand in grafting can opt for queen bee rearing by grafting in plastic cell cups.

\section{Conclusion}

The present study concludes that the Cupkit queen rearing technique is the best as it resulted in the maximum larval acceptance, cell raising and sealing, and emergence of gynes. Cupkit is an excellent technique for those who face difficulties while practicing Doolittle grafting method as fabrication of cell cups and grafting of larvae is not required. At this emergence rate $(54.67 \%)$, single use of apparatus will produce queen bees sufficient to cover the cost of the apparatus. Although the same apparatus can be used several times over the years. With proper handling, the apparatuses can last more than 5 years or until it is not damaged in any manner.

\section{ACKNOWLEDGEMENTS}

The authors are thankful to the Indian Council for Agricultural Research, New Delhi (India) for providing the financial assistance and Punjab Agricultural University, Ludhiana for providing facilities for carrying out the research.

\section{REFERENCES}

Ahmad S. B. and Dar S. A. (2013). Mass rearing of queen bees, Apis mellifera L. (Hym:Apidae) for bee colony development raised under the temperate conditions of 
Kashmir. The Bioscan., 8(3): 945-948.

Büchler, R., Andonov, S., Bienefeld, K., Costa, C., Hatjina, F., Kezic, N., Kryger, P., Spivak ,M., Uzunov2 A. and Wilde J. (2013). Standard methods for rearing and selection of Apis mellifera queens. J. Apic. Res., 52(1): 1-30.

Chang, S.Y. (1977). Effects of,size and type of queen cup on the production of royal jelly and acceptance by nurse bees. Master Thesis, National Chung Hsing University Taichung, Taiwan. Apic. Abstr., 2: 201/79.

Dodologlu, A., Emsen, B. and Genc, F. (2004). Comparison of some characteristics of queen honey bees (Apis mellifera L.) reared by usingDoolittle method and natural queen cells. J. App. Anim. Res., 26: 113-115.

El-Din, H.A.S. and Samni, M.A. (1990). Comparison of two types of queen cell cups for commercial royal jelly production in honey bee (Apis mellifera L.) colonies. Honey Bee. Sci., 11: 159-160.

Emsen, B., Dodologlu, A. and Genc, F. (2003). Effect of larvae age andgrafting on the larvae accepted rate and height of sealed queen cell(Apis mellifera L.). J. App. Anim. Res., 24: 201-206.

Gatoria, G.S., Aulakh, R.K., Chhuneja, P.K., Singh, B. and Kamaldeep (2004). Evaluation of queen cup-kit apparatus for mass rearing of Apis mellifera Linn. queen bees. Ins. Env., 10(3): 101-103.
Genc, F., Emsen, B. and Dodologlu, A. (2005). Effects of rearing periodand grafting method on the queen bee rearing. J. App. Anim. Res., 27(1): 45-48.

Goodman, R. (2008). Raising Queen Honey Bees. Agriculture Notes, ID: AG1194. State of Victoria, Department of Primary Industries. ISSN 1329-8062.

McKinley, W.M. (1963). Grafting- how it is done. Glean Bee Cult., 91: 404-409.

Nageh, S. M. O., Mabrouk, M. S. O. and Mohanna, K. M. (2010). Some factors affecting successful Apis mellifera queen rearing in Sohag. J. Agric. Sci., 18(1): 213-19.

Ruttner, F. (1988). Breeding techniques and selection for breeding of the honeybee. British Islets Bee Breeders Association. Derby, UK, pp 152.

Wilde, J., Woyke, J. and Wilde, J. (2002). Rearing honey bee queens in wax and plastic queen cell cups. In:Proceedings of the $6^{\text {th }}$ Asian Apicultural Association International Conference and World Apiexpo,Banglore on $24^{\text {th }}$ Feb- $1^{\text {st }}$ March, 2002,pp, 167.

Skowronek, W., Bieñkowska, M. and Kruk C. (2004). Changes in body weight of honeybee queens during their maturation. J. Apic. Sci., 48 (2): 61-68.

Woodward, D. (2007). Queen bee: Biology, rearing and breeding. Balclutha; New Zealand. 137 pp. 